\title{
Keputusan Investasi, Pendanaan, Kebijakan Dividen dan Price to Book Value Perusahaan Pertambangan di Bursa Efek Indonesia
}

\author{
Asep Alipudin ${ }^{1}$, Nur Hidayat ${ }^{2}$ \\ ${ }^{1}$ Universitas Pancasila, Jl. Srengseng Sawah, Jagakarsa, Jakarta Selatan 12640 \\ ${ }^{2}$ Universitas Jenderal Achmad Yani, Jl. Terusan Jenderal Gatot Subroto, Bandung, 40285
}

I N F O A R T I K E L

\section{JEL Classification}

G14

M21

Keywords:

investment decision,

funnding decisions,

dividend policy,

and price to book value

\section{A B S T R A C T}

The financial performance of the mining sector was having decline from 2011 to 2012. Price to book value illustrates the value of the company. This study examines the effect of investment decisions, financing, and dividend policy on price to book value. Samples were tested by 50 years of data mining company for 5 years. The results showed that the investment decisions affect the value of the company. The research result shows that financing policy and dividend policy no significant effect on firm value. This research contributes for empirical evidence related to the factors that affect the value of the company in the mining sector.

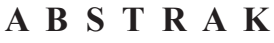

Kinerja keuangan sektor pertambangan sedang mengalami penurunan dari tahun 2011 sampai 2012. Price to Book Value menggambarkan nilai dari perusahaan. Penelitian ini menguji pengaruh keputusan investasi, pendanaan, dan kebijakan dividen terhadap price to book value. Sampel diuji sebanyak 50 data tahun perusahaan pertambangan selama 5 tahun. Hasil penelitian menunjukkan bahwa keputusan investasi berpengaruh terhadap nilai perusahaan. Adapun pendanaan dan kebijakan deviden berpengaruh tidak signifikan terhadap nilai perusahaan. Riset ini memberikan kontribusi tentang bukti empiris terkait faktor-faktor yang mempengaruhi nilai perusahaan pada sektor pertambangan moral.

\section{Pendahuluan}

Kinerja keuangan sektor pertambangan sedang mengalami penurunan dari tahun 2011 sampai 2012. Rasio Price to Book Value (PBV) perusahaan-perusahaan pertambangan mengalami penurunan dari tahun 2011 yang sebesar $5,15 \%$ turun menjadi $3,68 \%$ di tahun 2012. Kinerja keuangan sektor pertambangan berdasarkan rasio-rasio keuangan dapat dilihat dari beberapa indikator rasio keuangan antara lain: rasio Earning Per Share (EPS) yang menurun dari tahun 2008 sebesar Rp 303,00 menjadi sebesar Rp 263,00 di tahun 2012; rasio Book Value yang menurun dari tahun 2008 sebesar Rp 1.134,00 menjadi sebesar Rp 915,00 di tahun 2012 Debt to Equity Ratio (DER)

*Email Korespondensi: 1alipudin_asep@yahoo.com,2jnur_hidayat@yahoo.co.id 
sektor pertambangan yang meningkat dari tahun 2008 sebesar 1,31 x menjadi 1,79 x pada tahun 2012. Selain daripada kinerja keuangan yang menurun, kinerja saham perusahaan pertambangan juga menurun. Pada pertengahan Oktober 2012 kinerja saham-saham sektor pertambangan masih tertinggal dibandingkan sektor lainnya, meskipun Indeks Harga Saham Gabungan sempat mencatat rekor tertinggi selama lima kali berturut-turut. Berdasarkan data statistik PT Bursa Efek Indonesia hingga 19 Oktober 2012 secara year to date indeks sektor pertambangan tercatat turun hingga $24,63 \%$. Sementara saham sektor lain naik dan menjadi penyokong penguatan indeks.

Rasio Price to Book Value menggambarkan suatu nilai dari perusahaan. Nilai perusahaan dapat dilihat dari harga sahamnya, karena harga saham mencerminkan kinerja perusahaan. Semakin besar PBV maka semakin tinggi nilai perusahaan. Penggunaan indikator PBV ini didasarkan atas penelitian Fama (1978) yang dalam penelitiannya menggunakan konsep nilai pasar untuk mengukur nilai perusahaan. Nilai pasar tersebut merupakan nilai yang terbentuk oleh penawaran dan permintaan saham oleh para pelaku pasar dalam berinvestasi.

Investasi adalah setiap wahana di mana dana ditempatkan dengan harapan dapat memelihara atau menaikan nilai dan/atau memberikan hasil (return) yang positif. Dengan kata lain, investasi adalah menempatkan dana atau uang dengan harapan untuk memperoleh tambahan atau keuntungan tertentu atas uang atau dana tesebut. Hasil dari suatu investasi terdiri dari dua unsur utama, yaitu penghasilan berjalan seperti bunga, deviden, sewa, dan lainlain, dan capital-gain berupa kenaikan nilai karena harga jual lebih tinggi dari harga belinya. Dalam menanamkan dana atau investasi, seorang investor baik perorangan maupun institusi selalu dihadapkan pada hasil (return) dan risiko (risk). Seorang investor yang rasional akan memusatkan perhatiannya pada (1) tingkat return tertinggi dengan tingkat risiko tertentu atau (2) return tertentu dengan tingkat risiko yang rendah. Kedua kondisi tersebut menunjukkan investasi pada kondisi yang optimal. Ketika seseorang akan melakukan investasi, perhatian utama yang tidak terlepas dari pertimbangan investor, adalah tingkat bunga. Untuk itu dia akan membandingkan antara tingkat suku bunga dengan return yang mungkin akan dia peroleh dari investasi aset finansial lainnya. Tentu saja jika yang dipertimbangkan hanya aspek risiko maka investor akan memilih deposito karena dianggap tidak memiliki risiko. Akan tetapi jika mengharapkan hasil yang lebih besar maka akan memilih aset finansial lainnya, misal saham sebagai wahana investasinya. Dan jika itu pilihannya maka investor harus mempertimbangkan faktor risiko, karena semakin besar kemungkinan hasil yang akan diperoleh, tingkat risiko yang akan diterima pun semakin besar. Oleh karena itu, dalam mengambil keputusan investasi faktor tingkat risiko menjadi salah satu yang dipertimbangkan.

Keputusan investasi suatu perusahaan bisa dikatakan sebagai investasi modal perusahaan tersebut untuk dirasakan manfaatnya di masa yang akan datang. Namun, selain manfaat yang akan diterima perusahaan dari investasinya, perusahaan juga dihadapkan pada risiko atas investasi tersebut. Namun, menurut signaling theory, apabila perusahaan tersebut melakukan investasi, maka hal tersebut merupakan sinyal positif bagi investor mengenai prospek perusahaan di masa yang akan datang. Hal tersebut akan berdampak pada harga saham perusahaan yang meningkat sehingga dapat dikatakan bahwa nilai perusahaan tersebut juga meningkat.

Penelitian tentang keputusan keuangan pernah dilakukan oleh Hasnawati (2005) yang menemukan bahwa keputusan investasi, keputusan pendanaan, dan kebijakan dividen secara parsial berpengaruh positif terhadap nilai perusahaan. Kebijakan dividen secara langsung mempengaruhi nilai perusahaan dan secara tidak langsung keputusan investasi mempengaruhi nilai perusahaan melalui kebijakan dividen dan keputusan pendanaan. Jadi, keputusan investasi 
berpengaruh terhadap keputusan pendanaan, keputusan pendanaan berpengaruh terhadap kebijakan dividen, dan keputusan investasi berpengaruh terhadap kebijakan dividen.

Hasil penelitian lainnya yang berkaitan dengan keputusan pendanaan dan kinerja perusahaan menunjukkan variabel-variabel dan pengaruhnya terhadap keputusan pendanaan dan kinerja perusahaan. Hasil penelitian Sawir (2006) bahwa faktor-faktor yang mempengaruhi keputusan pendanaan antara lain: (1) Market to Book Ratio bepengaruh negatif terhadap keputusan pendanaan dengan utang; (2) Ukuran perusahaan berpengaruh positif terhadap keputusan pendanaan dengan utang; (3) Profitabilitas berpengaruh negatif terhadap keputusan pendanaan dengan utang. Sedangkan faktor-faktor yang mempengaruhi kinerja perusahaan adalah: (1) Market to Book Ratio bepengaruh positif terhadap kinerja perusahaan; (2) Profitabilitas berpengaruh positif terhadap terhadap kinerja perusahaan; dan (3) Dividen berpengaruh positif terhadap kinerja perusahaan. Dan secara simultan, keputusan pendanaan berpengaruh terhadap kinerja perusahaan serta sebaliknya, kinerja perusahaan berpengaruh terhadap keputusan pendanaan perusahaan.

Penelitian-penelitian di atas menunjukkan bahwa hasil penelitian mengindikasikan keputusan investasi, pendanaan, dan kebijakan dividen mempunyai pengaruh terhadap rasio Price To Book Value sebagai gambaran dari nilai perusahaan, namun hasil tersebut masih bervariasi. Oleh karena itu dalam penelitian ini akan menganalisis kembali dan mengembangkan temuan penelitian sebelumnya. Dalam penelitian ini akan menganalisa variabel CPA/BVA atau Ratio Capital Expenditure to Book Value of Asset sebagai indikator dari keputusan investasi, Debt to Equity Ratio sebagai indicator keputusan pendanaan, dan Dividend Payout Ratio sebagai indikator dari kebijakan dividen. CPA/BVA atau Ratio Capital Expenditure to Book Value of Asset merupakan salah satu proksi IOS (Invesment Opportunity Set) berbasis investasi yang digunakan dalam penilaian atas keputusan investasi suatu perusahaan. Dalam keputusan investasi ini menunjukkan bagaimana manajer keuangan suatu perusahaan menggunakan keterampilannya sehingga keputusan yang diambil mengenai investasinya menghasilkan net present value yang positif. CPA/BVA digunakan dalam penelitian ini karena merupakan proksi IOS yang berbasis investasi yang menunjukkan tingkat aktivitas yang tinggi. CPA/BVA atau rasio Capital Expenditure to Book Value of Asset menunjukkan adanya tambahan modal saham perusahaan yang dapat digunakan untuk tambahan investasi aktiva produktifnya. CPA/BVA merupakan perbandingan antara pertumbuhan asset dengan total asset perusahaan. (Jefri, 2008). Sementara itu Debt to Equity Ratio (DER) yang merupakan indikator dari keputusan pendanaan adalah perbandingan antara total utang perusahaan dengan total ekuitas perusahaan.

Penelitian ini bertujuan untuk mengetahui, menganalisis, membuktikan dan menguji pengaruh keputusan investasi, keputusan pendanaan, dan kebijakan dividen terhadap Price to Book Value (PBV) pada perusahaan pertambangan yang terdaftar di Bursa Efek Indonesia periode 2008-2012. Dengan tujuan seperti itu maka diharapkan dari hasil penelitian ini memberikan manfaat bagi para akademisi maupun para praktisi.

Berdasarkan latar belakang yang telah diuraikan di atas dan memperhatikan pentingnya pengambilan keputusan baik keputusan investasi, keputusan pendanaan, maupun keputusan dividen yang tepat yang diharapkan akan dapat meningkatkan Price to Book Value sebagai gambaran dari nilai perusahaan pada sektor pertambangan. Oleh karena itu peneliti tertarik untuk melakukan penelitian dengan menetapkan judul "Keputusan Investasi, Pendanaan, Dan Kebijakan Dividen Terhadap Price to Book Value (Studi Empiris pada Perusahaan Pertambangan yang Terdaftar di Bursa Efek Indonesia Periode 2008-2012)"

\section{Telaah Teori dan Pengembangan}




\section{Hipotesis}

\subsection{Teori Keagenan dan Teori Sinyal}

Para manajer memiliki tujuantujuan pribadi yang bersaing dengan tujuan memaksimalkan kekayaan pemegang saham. Para manajer diberi kekuasan oleh pemegang saham untuk mengambil keputusan, hal ini menciptakan potensi konflik kepentingan yang disebut teori keagenan (agency theory). Teori agensi dilandasi oleh asumsi yang menyatakan bahwa setiap individu berusaha untuk memaksimalkan fungsi yang dimilikinya. Sebuah agensi diartikan sebagai hubungan atas dasar kesepakatan dua pihak, di mana satu pihak sebagai agen setuju untuk bertindak atas dasar kepentingan pihak principal atau pemilik modal. Hal ini sejalan dengan model Rochester di mana perusahaan merupakan suatu "black box" yang melakukan berbagai upaya untuk memenuhi relevansi kondisi marginal dengan memperhatikan masukan dan keluaran dalam mencapai maksimisasi laba perusahaan.

Inti dari hubungan keagenan adalah adanya pemisahan antara kepemilikan (di pihak principal atau investor) dan pengendalian (di pihak agent atau manajer). Investor memiliki harapan bahwa manajer akan menghasilkan return dari uang yang mereka investasikan. Oleh karena itu, kontrak yang baik antara investor dan manajer adalah kontrak yang mampu menjelaskan spesifikasi-spesifikasiapa saja yang harus dilakukan manajer dalam mengelola dana para investor, dan spesifikasi tentang pembagian return antara manajer dengan investor. Idealnya, investor dan manajer menandatangani kontrak yang komplit, yang menspesifikasikan secara tepat apa saja yang akan dilakukan manajer pada segala kemungkinan yang akan terjadi, dan bagaimana laba perusahaan akan dialokasikan. Namun, sebagian besar faktor-faktor kontijensi sulit untuk diprediksi sebelumnya, sehingga kontrak yang lengkap sulit untuk diwujudkan. Dengan demikian, investor harus memberikan hak pengendalian residual (residual control right) kepada manajer, yaitu hak untuk membuat keputusan dalam kondisi-kondisi tertentu yang sebelumnya belum terlihat dalamkontrak(Sawir, 2006). Kreditur memantau opersasi perusahaan untuk mencegah peminjam mengambil risiko yang berlebihan, karena pengambilan risiko cenderung menguntungkan peminjam dibandingkan yang meminjamkan. Sekalipun utang dijamin dengan aktiva, namun jaminan dapat dihamburkan melalui pemeliharaan yang tidak memadai dan pembayaran dividen serta gaji yang berlebihan kepada pemilik. Untuk pemegang ekuitas, aktivitas pemantauan akan dikonsentrasikan pada tindakan mencegah manajemen mengambil keuntungan atas beban pemegang saham. Pemantauan secara umum dipermudah dengan menggunakan perjanjian yang membatasi aktivitas manajemen, dengan demikian akan meningkatkan biaya keuangan.

Kedua Teori sinyal, dikembangkan oleh Ross (1976), dimana Ross berusaha untuk mengeksplorasi struktur modal perusahaan menjadikan adanya asymmetric information sebagai landasan dalam menentukan struktur modal perusahaan. Teori sinyal merupakan teori yang memberikan dorongan kepada perusahaan untuk memberikan informasi kepada pihak yang membutuhkan informasi tersebut. Menurut Brigham dan Houston (2006), isyarat atau sinyal adalah suatu tindakan yang diambil perusahaan untuk memberi petunjuk bagi investor tentang bagaimana manajemen memandang prospek perusahaan. Sedangkan menurut Hasnawati (2005) signalling theory menyatakan pengeluaran investasi memberikan sinyal positif tentang pertumbuhan perusahaan dimasa yang akan datang, sehingga meningkatkan harga saham sebagai indikator nilai perusahaan. Teori sinyal ini memberikan gambaran dimana di dalamnya memuat informasi yang begitu penting bagi investor untuk keputusan investasinya. Alasannya karena informasi tersebut memuat catatan, keterangan, dan gambaran dari suatu perusahaan pada masa lalu maupun masa kini dan masa yang akan datang.

\subsection{Price to Book Value}

Price to Book Value (PBV) merupakan 
rasio yang menggambarkan persepsi para pelaku pasar atau investor terhadap suatu perusahaan. Rasio ini juga yang menggambarkan seberapa besar para investor menilai perusahaan dengan kata lain nilai dari perusahaan tersebut. Semakin besar rasio ini maka semakin besar pula ekspektasi para investor terhadap suatu perusahaan tersebut. Para investor menilai tinggi prospek perusahaan tersebut karena kinerja keuangan masa lalu serta di masa yang akan datang.

\subsection{Keputusan Investasi, Pendanaan dan Kebijakan Deviden}

Keputusan investasi adalah keputusan keuangan (financial decision) tentang aktiva mana yang harus dibeli perusahaan. Aktiva tersebut berupa aktiva riil (real assets). Aktiva riil dapat berupa aktiva nyata (tangible assets) seperti mesin, tanah, gedung, perlengkapan, atau dapat berupa aktiva tidak nyata (intangible assets), seperti paten, hak cipta, merk, dan lainlain. Keputusan pendanaan adalah keputusan keuangan tentang dari mana dana untuk membeli aktiva perusahaan berasal. Dana atau modal yang digunakan ada dua macam, yaitu: (1) modal asing seperti utang bank, obligasi, dan (2) modal sendiri seperti laba ditahan, saham. Kebijakan pembagian dividen merupakan salah satu keputusan penting bagi perusahaan dalam bidang keuangan. Kebijakan ini akan melibatkan dua pihak yang berkepentingan dan saling bertentangan, yaitu kepentingan para pemegang saham dengan dividennya dan kepentingan perusahaan dengan saldo labanya.

\subsection{Penelitian Terdahulu}

\begin{tabular}{|c|c|c|c|c|c|}
\hline No & Peneliti & $\begin{array}{c}\text { Judul } \\
\text { Penelitian }\end{array}$ & Hasil & Persamaan & Perbedaan \\
\hline 1 & $\begin{array}{l}\text { Anwar } \\
(2001)\end{array}$ & $\begin{array}{l}\text { Pengaruh Kinerja } \\
\text { Keuangan terhadap } \\
\text { Nilai Perusahaan } \\
\text { dengan Pengungkapan } \\
\text { Corporate Social } \\
\text { Responsibility } \\
\text { dan Kepemilikan } \\
\text { Manajerial sebagai } \\
\text { Variabel Pemoderasi }\end{array}$ & $\begin{array}{l}\text { Secara simultan } \\
\text { variabel ROA, } \\
\text { interaksi antara ROA } \\
\text { dengan CSR, dan } \\
\text { interaksi antara ROA } \\
\text { dengan KM tidak } \\
\text { berpengaruh terhadap } \\
\text { nilai perusahaan. }\end{array}$ & $\begin{array}{l}\text { Variabel dependen } \\
\text { yang digunakan yaitu } \\
\text { nilai perusahaan }\end{array}$ & $\begin{array}{l}\text { Proksi nilai } \\
\text { perusahaan } \\
\text { penelitian } \\
\text { menggunakan } \\
\text { Tobins'Q }\end{array}$ \\
\hline 2 & $\begin{array}{l}\text { Sudiyanto } \\
\text { dan } \\
\text { Puspitasari } \\
(2010)\end{array}$ & $\begin{array}{l}\text { Pengaruh Kebijakan } \\
\text { Perusahaan Terhadap } \\
\text { Nilai Perusahaan } \\
\text { Dengan Kinerja } \\
\text { Perusahaan Sebagai } \\
\text { Variabel Intervening }\end{array}$ & $\begin{array}{l}\text { Insentif manajer } \\
\text { dan Capex tidak } \\
\text { berpengaruh pada } \\
\text { nilai perusahaan, } \\
\text { leverage keuangan dan } \\
\text { kinerja perusahaan } \\
\text { berpengaruh positif } \\
\text { terhadap nilai } \\
\text { perusahaan. }\end{array}$ & $\begin{array}{l}\text { Variabel dependen } \\
\text { yang digunakan yaitu } \\
\text { nilai perusahaan }\end{array}$ & $\begin{array}{l}\text { Terdapat } \\
\text { variabel kinerja } \\
\text { keuangan } \\
\text { sebagai } \\
\text { variabel } \\
\text { intervening }\end{array}$ \\
\hline 3 & $\begin{array}{l}\text { Wijaya dan } \\
\text { Wibawa } \\
(2009)\end{array}$ & $\begin{array}{l}\text { Pengaruh Keputusan } \\
\text { Investasi, Keputusan } \\
\text { Pendanaan, Dan } \\
\text { Kebijakan Dividen } \\
\text { Terhadap Nilai } \\
\text { Perusahaan }\end{array}$ & $\begin{array}{l}\text { Keputusan investasi, } \\
\text { keputusan pendanaan, } \\
\text { dan kebijakan } \\
\text { dividen berpengaruh } \\
\text { positif terhadap nilai } \\
\text { perusahaan. }\end{array}$ & $\begin{array}{l}\text { Variabel-variabel yang } \\
\text { digunakan semuanya } \\
\text { sama }\end{array}$ & $\begin{array}{l}\text { Perbedaan } \\
\text { objek, periode, } \\
\text { dan metode } \\
\text { penelitian }\end{array}$ \\
\hline 4 & $\begin{array}{c}\text { Alfredo } \\
\text { (2011) }\end{array}$ & $\begin{array}{l}\text { Pengaruh Kinerja } \\
\text { Keuangan Terhadap } \\
\text { Nilai Perusahaan } \\
\text { (Kebijakan Dividen } \\
\text { Sebagai Variabel } \\
\text { Moderating) } \\
\text { Pada Perusahaan } \\
\text { Manufaktur Di Bursa } \\
\text { Efek Indonesia }\end{array}$ & $\begin{array}{l}\text { Likuiditas dan } \\
\text { leverage tidak } \\
\text { berpengaruh } \\
\text { signifikan terhadap } \\
\text { nilai perusahaan, } \\
\text { Profitabilitas } \\
\text { berpengaruh } \\
\text { signifikan terhadap } \\
\text { nilai perusahaan. }\end{array}$ & $\begin{array}{l}\text { Variabel dependen } \\
\text { yang digunakan yaitu } \\
\text { nilai perusahaan }\end{array}$ & $\begin{array}{l}\text { Adanya vaiabel } \\
\text { kebijakan } \\
\text { dividen sebagai } \\
\text { variabel } \\
\text { moderating }\end{array}$ \\
\hline
\end{tabular}




\subsection{Kerangkan Pemikiran}

Gambar 1. Kerangka Pemikiran

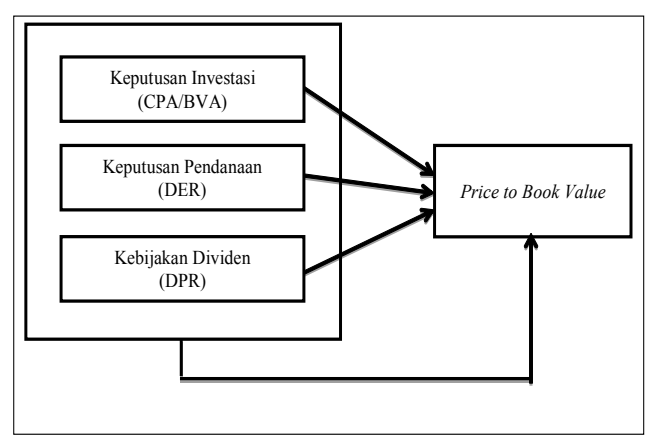

Berdasarkan kerangka pemikiran dan kajian teori sebelumnya dengan latar belakang permasalahan yang sudah dipaparkan, maka dirumuskan hipotesis sebagai berikut :

H1: Keputusan investasi berpengaruh signifikan terhadap Price to Boo Value

$\mathrm{H} 2$ : Keputusan pendanaan berpengaruh signifikan terhadap Price to Book Value

H3: Kebijakan dividen berpengaruh signifikan terhadap Price to Book Value

H4: Secara simultan keputusan investasi, keputusan pendanaan, dan kebijakan dividen berpengaruh signifikan terhadap

Price to Book Value.

\section{Metode Penelitian}

Untuk dapat memperoleh jawaban atas penelitian yang dilakukan, maka penulis menggunakan alat regresi berganda, yaitu metode yang digunakan untuk menganalisis hubungan antar variabel. Analisis regresi linier berganda adalah analisis untuk mengukur besarnya pengaruh antara dua atau lebih variabel independen terhadap satu variabel dependen dan memprediksi variabel dependen dengan menggunakan variabel independen. Hubungan tersebut dapat digambarkan dalam bentuk persamaan yang menghubungkan variabel $\mathrm{Y}$ (dependen) dengan dua atau lebih variabel $\mathrm{X}$ (independen). Persamaan dari model regresi tersebut bias dituliskan sebagai berikut:

$$
\mathrm{Y}=\mathrm{a}+\mathrm{b}_{1} \mathrm{X}_{1}+\mathrm{b}_{2} \mathrm{X}_{2}+\mathrm{b}_{3} \mathrm{X}_{3}+\mathrm{e}
$$

Keterangan:

$$
\mathrm{Y}=\mathrm{PBV}
$$

$$
\begin{aligned}
& \mathrm{a}=\text { konstanta } \\
& \mathrm{b}=\text { koefisien regresi } \\
& \mathrm{X}_{1}=\text { CPA/BVA } \\
& \mathrm{X}_{2}=\text { DER } \\
& \mathrm{X}_{3}=\text { DPR } \\
& \mathrm{e}=\text { variabel lain di luar model }
\end{aligned}
$$

Jumlah perusahaan yang menjadi sampel penelitian sebanyak 10 perusahaan dari 37 perusahaan pertambangan yang terdaftar di Bursa Efek Indonesia pada tahun 2008 sampai 2012, sebanyak 8 (delapan) perusahaan terkoreksi tidak melaporkan secara rutin laporan keuangannya kepada Bursa Efek Indonesia, sebanyak 8 (delapan) perusahaan tidak mencatatkan laba bersih, dan 11 (sebelas) perusahaan tidak membagikan dividen tunai selama periode 2008-2012.

Tipe-tipe variabel dalam penelitian ini yaitu variabel bebas (Independent Variable) dan variabel terikat (Dependent Variable):

1. Keputusan investasi melalui proksi rasio CPA/BVA atau Capital Expenditure to Book Value of Asset. Rasio CPA/BVA atau Capital Expenditure to Book Value of Asset merupakan perbandingan antara pertumbuhan asset tetap setiap tahun dengan total asset yang dimiliki oleh perusahaan.

2. Debt to Equity Ratio (DER) merupakan indikator keputusan pendanaan. DER yang besar mengindikasikan perusahaan banyak menggunakan utangnya untuk membiayai asset yang dimilikinya. Namun sebaliknya apabila DER perusahaan bernilai kecil maka risiko yang ditanggung perusahaan juga relatif kecil sehingga pelaku pasar berani menilai positif bagi perusahaan.

3. Dividend Payout Ratio (DPR) merupakan indikator dari kebijakan dividen perusahaan. DPR yang kecil menggambarkan perusahaan dalam membagikan dividen kepada para pemegang saham lebih kecil daripada laba yang ditahannya. DPR yang besar menggambarkan jumlah dividen yang dibagikan kepada para pemegang saham lebih besar daripada jumlah laba yang ditahannya. 
4. Price to Book Value (PBV) merupakan variabel terikat atau variabel dependen. PBV merupakan perbandingan antara harga saham perusahaan dengan nilai bukunya. PBV yang tinggi mengindikasikan nilai perusahaan yang tinggi pula dari para pelaku pasar, sedangkan PBV yang rendah menggambarkan penilaian yang rendah pula dari para pelaku pasar atas perusahaan tersebut.

Pengujian dilakukan untuk memperoleh nilai yang tidak bias karena data yang digunakan adalah data sekunder dan jenis data yang beragam. Uji ini terdiri dari uji normalitas, uji multikolinearitas, uji heteroskedastisitas, dan uji autokorelasi. Apabila ada satu syarat saja yang tidak terpenuhi makka hasil analisis regresi tidak dapat dikatakan bersifat BLUE.

1. Uji Normalitas

Uji normalitas bertujuan untuk menguji apakah dalam model regresi, variabel dependen dan variabel dependen keduanya mempunyai distribusi normal atau tidak. Beberapa metode uji normalitas yaitu dengan melihat penyebaran data pada sumber diagonal pada grafik Normal P-P Plot of regression standardized atau dengan uji One Sample Kolmogorov Smirnov. angka Tolerance kurang dari 0,1, maka antar variabel bebas terjadi persoalan multikolinearitas.

3. Uji Heteroskedastisitas

Pengujian ini digunakan untuk mengetahui ada tidaknya heteroskedastisitas atau untuk mengetahui ada atau tidaknya ketidaksamaan varian dari residual pada model regresi. Pengujian dilakukan dengan menggunakan Uji Spearman's rho. Apabila nilai signifikansi korelasi antara nilai residual (unstandardized residual) kurang dari 0,05 maka pada model regresi terjadi masalah heteroskedastisitas. Pengujian ini dapat pula dengan melihat pola titik-titik pada Scatterplots regresi.

4. Uji Autokorelasi

Uji autokorelasi bertujuan untuk menguji apakah dalam suatu model regresi ada atau tidaknya korelasi antara residual pada satu pengamatan dengan pengamatan lain. Jika terjadi korelasi maka dinamakan ada masalah autokerelasi. Uji autokorelasi dapat dilihat dari nilai Durbin Watson (DW test). Pengambilan keputusan ada tidaknya korelasi dapat digambarkan sebagai berikut:

Tabel 2.

Pengambilan Keputusan Uji Autokorelasi

\begin{tabular}{lcc}
\hline \multicolumn{1}{c}{ Hipotesis nol } & Keputusan & Jika \\
\hline Tidak ada autokorelasi positif & Tolak & $0<\mathrm{d}<\mathrm{dl}$ \\
Tidak ada autokorelasi positif & No decision & $\mathrm{dl} \leq \mathrm{d} \leq \mathrm{du}$ \\
Tidak ada korelasi negatif & Tolak & $4-\mathrm{dl}<\mathrm{d}<4$ \\
Tidak ada korelasi negatif & No decision & $4-\mathrm{du} \leq \mathrm{d} \leq 4-\mathrm{dl}$ \\
Tidak ada autokorelasi positif/negatif & Tidak ditolak & $\mathrm{du}<\mathrm{d}<4-\mathrm{du}$ \\
\hline
\end{tabular}

2. Uji Multikolinearitas

Metode ini digunakan untuk mengetahui ada atau tidaknya hubungan linear antar variabel independen dalam model regresi. Beberapa metode uji yang digunakan yaitu dengan melihat nilai Tolerance dan Varience Inflation Factor (VIF). Prasyarat yang harus dipenuhi dalam model regresi yaitu tidak adanya multikolinearitas. Jika nilai VIF lebih besar dari 5 dan mempunyai
Pengujian Hipotesis menggunakan beberapa uji yaitu sebagai berikut :

1. Uji Determinasi $\mathrm{R}^{2}$

Persentase variasi dari variabel independen yang mampu menjelaskan variasi dari variabel dependen, sedangkan persentase sisanya adalah variasi dari variabel independen lain yang mempengaruhi tetapi tidak dimasukkan dalam model. Adjusted $R$ Square dapat mengukur sumbangan 
pengaruh jika dalam regresi menggunakan lebih dari dua variabel independen. (Priyatno, 2010)

2. Uji Parsial

Untuk menguji signifikansi dari nilai koefisien regresi semua variabel independen dalam persamaan regresi, dapat dilihat dari nilai $t$ dan nilai signifikansinya. Hal ini dilakukan untuk menguji apakah secara parsial masing - masing variabel independen memiliki pengaruh yang signifikan terhadap variabel dependen. Dasar pengambilan keputusan: Berdasarkan probabilitas

Jika p-value $<0,05$, maka Ho ditolak.

Jika p-value $>0,05$, maka Ho diterima.
Berdasarkan probabilitas

Jika p-value $<0,05$, maka Ho ditolak.

Jika p-value $>0,05$, maka Ho diterima.

Berdasarkan F hitung terhadap F tabel

Jika F hitung $>$ F tabel, maka Ho ditolak.

Jika $\mathrm{F}$ hitung $<\mathrm{F}$ tabel, maka Ho diterima.

(Priyatno, 2010)

\section{Hasil Penelitian Dan Pembahasan}

Deskriptif statistik merupakan tahap awal dalam proses pengujian data atau pengujian hipotesis dalam penelitian yang bersumber dari data sekunder. Analisis deskriptif dari masingmasing variabel dalam penelitian ini adalah sebagai berikut:

Tabel 3

Statistik deskriptif

\begin{tabular}{lcccccc}
\hline & N & Minimum & Maximum & Mean & $\begin{array}{c}\text { Std. } \\
\text { Deviation }\end{array}$ & Variance \\
\hline PBV & 50 & .53 & 33.23 & 3.5756 & 4.98651 & 24.865 \\
CPABVA & 50 & -4.60 & 2.15 & .0540 & .77942 & .607 \\
DER & 50 & .07 & 5.26 & 1.2936 & 1.15420 & 1.332 \\
DPR & 50 & .40 & 81.35 & 32.6314 & 24.47035 & 598.798 \\
Valid N (listwise) & 50 & & & & & \\
\hline
\end{tabular}

Tabel 4

Hasil Pengujian Hipotesis

\begin{tabular}{|c|c|c|c|c|c|c|}
\hline & \multirow[t]{2}{*}{ Model } & \multicolumn{2}{|c|}{$\begin{array}{l}\text { Unstandardized } \\
\text { Coefficients }\end{array}$} & \multirow{2}{*}{$\begin{array}{c}\text { Standardized } \\
\text { Coefficients } \\
\text { Beta }\end{array}$} & \multirow[t]{2}{*}{$\mathbf{T}$} & \multirow[t]{2}{*}{ Sig. } \\
\hline & & B & Std. Error & & & \\
\hline \multirow{4}{*}{1} & (Constant) & .174 & .083 & & 2.109 & .040 \\
\hline & CPABVA & .402 & .114 & .454 & 3.510 & .001 \\
\hline & DER & .160 & .114 & .188 & 1.403 & .167 \\
\hline & DPR & -.112 & .101 & -.139 & -1.104 & .275 \\
\hline
\end{tabular}

a. Dependent Variable: PBV

Berdasarkan $\mathrm{F}$ hitung terhadap $\mathrm{F}$ tabel

Jika $-\mathrm{t}$ tabel $\leq \mathrm{t}$ hitung $\leq \mathrm{t}$ tabel, maka Ho diterima.

Jika - $t$ hitung $\leq-\mathrm{t}$ tabel atau $\mathrm{t}$ hitung $>\mathrm{t}$ tabel, maka Ho ditolak. (Priyatno, 2010)

3. Uji Simultan

Uji simultan (Uji F) digunakan untuk menguji apakah secara bersama-sama seluruh variabel independen mempunyai pengaruh signifikan terhadap variabel dependen. Dasar pengambilan keputusan:
Berdasarkan Tabel 3 di atas dapat diketahui bahwa:

1. Price to Book Value (PBV) mempunyai nilai minimum sebesar $0,53 \%$., nilai maksimum sebesar 33,23\% pada tahun 2012. Sementara itu untuk nilai rata-rata dan standar deviasi dari PBV adalah masing-masing sebesar $3,5756 \%$ dan $4.98651 \%$ yang menunjukkan data tersebut mempunyai sebaran yang agak luas, sedangkan untuk nilai variance dari PBV adalah sebesar $24.865 \%$. 
2. Capital Expenditure to Book Value of Asset (CPABVA) mempunyai nilai minimum sebesar $-4,60 \%$ pada tahun 2011, dan untuk nilai maksimumnya sebesar $2,15 \%$ pada tahun 2011. Sementara itu untuk nilai ratarata dari CPABVA adalah sebesar $0,0540 \%$. Hal ini menunjukkan pertumbuhan dari asset perusahaan-perusahaan dalam industri pertambangan tidak terlalu besar setiap tahunnya. Sementara itu untuk nilai standar deviasi dan variance dari CPABVA adalah masing-masing sebesar 0,77942\% dan $0,607 \%$.

3. Nilai minimum dari Debt to Equity Ratio (DER) pada perusahaan-perusahaan industri pertambangan adalah sebesar $0,07 \%$ dan nilai maksimumnya adalah sebesar 5,26\%, sedangkan nilai rata-rata dari DER adalah sebesar 1,2936\%. Hal ini menunjukkan bahwa tingkat leverage perusahaan-perusahaan pertambangan tidak terlalu tinggi pada periode 2008 sampai 2012. Sementara itu untuk nilai standar deviasi dari DER adalah sebesar 1,15420\% yang menggambarkan bahwa sebaran data untuk DER tidak terlalu luas, sedangkan untuk nilai variance DER adalah sebesar $1,332 \%$.

4. Nilai minimum dari Dividend Payout Ratio (DPR) untuk perusahaan-perusahaan di industri pertambangan pada periode 2008 sampai 2012 sebesar $0,40 \%$ sedangkan nilai maksimumnya sebesar $81,35 \%$. Sementara itu untuk nilai rata-rata DPR dan standar deviasinya adalah masingmasing sebesar $32,6314 \%$ dan $24,47035 \%$ yang menunjukkan bahwa sebaran data untuk DPR pada perusahaan-perusahaan industri pertambangan dalam periode penelitian cukup luas. Hal tersebut juga dapat dibuktikan dengan nilai variance dari DPR yang sangat besar yaitu 598,798\%.

Pertama, berdasarkan hasil penelitian yang telah dilakukan menunjukkan bahwa keputusan investasi melalui CPABVA berpengaruh signifikan terhadap Price to Book
Value. Para pemegang saham beranggapan bahwa dengan adanya investasi baru dalam suatu perusahaan maka perusahaan tersebut memiliki propek positif di masa yang akan datang. Oleh karena itu, keputusan investasi oleh suatu perusahaan sangat penting untuk meningkatkan nilai perusahaan yang digambarkan oleh rasio PBV itu sendiri. Hasil penelitian ini mendukung hasil penelitian dari Gany (2012) yang menemukan bahwa keputusan investasi dengan variabel CPA/BVA berpengaruh positif dan signifikan terhadap nilai perusahaan. Pengeluaran modal perusahaan (capital expenditure) yang tercermin dalam sisi asset perusahaan sangat penting untuk meningkatkan nilai perusahaan karena memberikan sinyal tentang pertumbuhan pendapatan perusahaan yang diharapkan di masa yang akan datang.

Kedua, hasil penelitian yang telah dilakukan menunjukkan bahwa keputusan pendanaan melalui DER tidak berpengaruh signifikan terhadap Price to Book Value. Dengan gambaran seperti itu maka bertentangan dengan teori sinyal yang sudah dinyatakan sebelumnya bahwa para pemegang saham nilai perusahaan akan meningkat apabila perusahaan meningkatkan proporsi hutangnya. Dengan begitu maka para pemegang saham beranggapan bahwa dengan adanya peningkatan proporsi hutang maka akan meningkat pula risiko yang akan diterima olehnya di masa yang akan datang. Hasil penelitian ini mendukung hasil penelitian dari Gany (2012) yang menemukan bahwa keputusan pendanaan tidak berpengaruh negatif terhadap nilai perusahaan. Dalam penelitiannya juga menggunakan DER sebagai ukuran dari keputusan pendanaan.

Ketiga, hasil penelitian yang telah dilakukan menunjukkan bahwa kebijakan dividen tidak berpengaruh signifikan terhadap Price to Book Value. Dengan hasil penelitian ini, maka walaupun perusahaan-perusahaan pertambangan pada periode penelitian selalu membagikan dividen namun tidak dapat mempengaruhi penilaian dari para investor atau pemegang saham dengan kata lain investor 
memberikan sinyal negatif atas kebijakan dividen dari perusahaan-perusahaan tersebut. Hasil penelitian ini mendukung hasil penelitian dari Umi (2008) yang menemukan bahwa dengan menggunakan analisis regresi nilai perusahaan dipengaruhi oleh kebijakan investasi dan kebijakan pendanaan tetapi diketahui bahwa kebijakan dividen tidak berpengaruh signifikan terhadap nilai perusahaan.

Keempat, hasil penelitian yang telah dilakukan bahwa keputusan investasi, pendanaan, dan kebijakan dividen secara simultan berpengaruh signifikan terhadap Price to Book Value. Dari hasil tersebut di atas dapat memberikangambaran bahwa dengan kombinasi optimal dari ketiga kebijakan tersebut maka menghasilkan nilai yang baik bagi perusahaan dengan kata lain akan meningkatkan Price to Book Value. Hasil penelitian ini mendukung hasil penelitian dari oleh Putri dan Iin (2009) yang menemukan bahwa keputusan investasi, keputusan pendanaan, dan kebijakan dividen secara parsial berpengaruh positif terhadap nilai perusahaan. Hasil penelitiannya mengharuskan bahwa manajer keuangan harus mampu mengambil ketiga keputusan tersebut secara efektif dan efisien.

\section{Simpulan, Keterbatasan dan Implikasi Hasil Penelitian}

Berdasarkan hasil penelitian, maka penulis dapat menarik kesimpulan sebagai jawaban atas rumusan masalah sebelumnya sekaligus sebagai pembuktian dari hipotesis. Berdasarkan hasil penelitian sebelumnya, maka dapat disimpulkan bahwa keputusan investasi (CPABVA) secara parsial berpengaruh signifikan terhadap PBV. Dengan hasil seperti itu menggambarkan keputusan investasi berpengaruh positif dan signifikan terhadap PBV. Hal tersebut menunjukkan bahwa keputusan investasi yang dilakukan perusahaanperusahaan pertambangan menghasilkan nilai bagi perusahaan di masa yang akan datang dan dinilai tinggi oleh investor. Berdasarkan hasil penelitian sebelumnya, maka dapat disimpulkan bahwa keputusan pendanaan (DER) secara parsial tidak berpengaruh signifikan terhadap PBV. Hal tersebut menggambarkan bahwa keputusan pendanaan tidak memiliki dampak yang signifikan terhadap PBV namun tetap memiliki pengaruh terhadap PBV, tetapi tidak signifikan. Dengan begitu maka para pemegang saham beranggapan bahwa dengan adanya peningkatan proporsi hutang maka akan meningkat pula risiko yang akan diterima olehnya di masa yang akan datang. Berdasarkan hasil penelitian sebelumnya, maka dapat disimpulkan bahwa kebijakan dividen (DPR) secara parsial tidak berpengaruh signifikan terhadap PBV. Hal tersebut menggambarkan bahwa kebijakan dividen tidak memiliki dampak yang signifikan terhadap PBV dengan kata lain kebijakan dividen berpengaruh negatif terhadap PBV. Dengan begitu para investor menganggap bahwa dengan semakin tingginya dividend payout ratio yang ditetapkan perusahaan maka akan semakin kecil dana yang tersedia untuk ditanamkan oleh perusahaan, sehingga prospek pertumbuhan perusahaan kedepan menjadi lebih kecil. Berdasarkan hasil penelitian sebelumnya, maka dapat disimpulkan bahwa keputusan investasi (CPABVA), keputusan pendanaan (DER), dan kebijakan dividen (DPR) secara simultan berpengaruh signifikan terhadap PBV. Dengan demikian, kombinasi yang optimal dari ketiga kebijakan tersebut mampu memberikan sinyal positif bagi para pemegang sahamnya yang membuat harga saham perusahaanperusahaan tersebut dapat naik sehingga pada akhirnya nilai PBV pun ikut naik.

Meskipun penelitian ini sudah menggunakan teknik yang sejalan dengan prosedur penelitian, namun masih ada kekurangan dalam penelitian ini, maka terdapat beberapa keterbatasan. Penelitian ini hanya mengambil populasi dan sampel pada perusahaan-perusahaan pertambangan di Bursa Efek Indonesia pada periode tahun 2008 sampai tahun 2012. Dengan kriteria pemilihan sampel tertentu, maka jumlah perusahaan yang menjadi sampel penelitian adalah sebanyak 10 perusahaan, sehingga jumlah data yang 
terkumpul adalah sebanyak 50. Dengan pendeknya periode penelitian dan jumlah data yang terbatas tersebut, maka hasilnya pun terlihat kurang optimal. Berdasarkan hasil uji determinasi dapat diketahui nilai Adjusted $R$ Square adalah sebesar 0,285 atau $28,50 \%$ sedangkan sisanya sebesar $71,50 \%$ dipengaruhi atau dijelaskan oleh variabel lain yang tidak dimasukkan dalam model penelitian. Hasil tersebut dapat menggambarkan bahwa model regresi dalam penelitian ini kurang mendukung untuk hasil penelitian yang optimal. Hal tersebut disebabkan jumlah perusahaan pertambangan yang terdaftar di Bursa Efek Indonesia pada periode penelitian jumlahnya sedikit apalagi dikurangi dengan pemilihan sampel tertentu sehingga jumlah sampel pun sangat terbatas. Selain itu, variabel yang digunakan dalam penelitian ini hanya mengggunakan variabel dari faktor internal perusahaan saja, tidak menggunakan faktor eksternal sehingga hasil penelitian tidak dapat menggambarkan situasi secara keseluruhan. Namun, hasil penelitian ini sejalan dengan hasil penelitian-penelitian sebelumnya yang mana hasil uji determinasinya memiliki nilai Adjusted R Square yang kecil.

Untuk para akademisi menggunakan proksi lain dengan proksi berbasis investasi seperti investment to net sales ratio, ratio of capita additions to firm value, investment intensity, ratio capital addition to asset book value, dan investment to earning ratio, maupun proksi berbasis harga seperti market to book value of equity, market to book value of asset, dan price to earning ratio. Kemudian disarankan juga untuk penelitian selanjutnya menggunakan variabel eksternal serta menambah jumlah perusahaan di industri yang lainnya sehingga jumlah sampel yang digunakan lebih banyak dan agar hasil penelitiannya lebih optimal. Untuk para praktisi khususnya di sektor industri pertambangan adalah untuk dapat meningkatkan investasinya terlebih pada pengeluaran modal perusahaan (capital expenditure) karena para pelaku pasar sangat merespon positif apabila ada keputusan investasi yang dibuat sehingga nilai perusahaan akan meningkat. Kemudian untuk para manajer keuangan sekiranya dapat memberikan perhatian lebih terhadap keputusan pendanaan dan kebijakan dividen yang dibuatnya sehingga keputusan-keputusan tersebut dapat mendapatkan hasil yang optimal sehingga investor maupun para pelaku pasar dapat merespon dengan positif dan nilai PBV akan meningkat.

\section{Daftar Pustaka}

Agnes Sawir, 2005. Analisis Kinerja Keuangan dan Perencanaan Keuangan Perusahaan. PT. Gramedia Pustaka Utama. Jakarta.

Agnes Sawir, 2006. Keputusan Pendanaan, Restruktrisasi Utang, Struktur Kepemilikan dan Kinerja Perusahaan. Disertasi. Program Doktor Ilmu Ekonomi Universitas Persada Indonesia Y.A.I., Jakarta.

Fama, E. F. 1978. The Effect of a Firm's Investment and Financing Decision on the Welfare of its Security Holders. American Economic Review 68: 272-28.

Fama, Eugene F and French, Kenneth R, 1998, Taxes, Financing Decision, and Firm Value, The Journal of Finance; Vol. LIII No. 3, June, pp. 819-843

Gany Ibrahim F. 2012. Pengaruh Keputusan Investasi, Keputusan Pendanaan, dan Kebijakan Dividen Terhadap Nilai Perusahaan. Skripsi. Fakultas Ekonomi, Universitas Diponegoro. Semarang.

Hasnawati, S. 2005a. Implikasi Keputusan Investasi, Pendanaan, dan Dividen Terhadap Nilai Perusahaan Publik di Bursa Efek Jakarta. Usahawan: No. 09/Th XXXIX. September 2005: 33-41.

Jefri Riyadi K. Invesment Opportunity Set (IOS) dan Realisasi Pertumbuhan Perusahaan dalam Menerapkan Kebijakan Pendanaan dan Kebijakan Dividen : Studi Kasus Pada Perusahaan di Bursa Efek Indonesia (2004-2007). Karya Akhir. Program Studi Magister Manajemen, Universitas Indonesia. Jakarta.

Murtini, Umi. 2008. "Pengaruh Kebijakan Manajemen Keuangan terhadap Nilai 
Perusahaan". Jurnal Riset Akuntansi dan Keuangan. Vol. 4, No. 1 Februari.

Putri Prihatin N dan Iin Indarti. 2009. Pengaruh Keputusan Investasi, Keputusan Pendanaan, dan Kebijakan Dividen Terhadap Nilai Perusahaan (Studi Kasus Pada Perusahaan Manufaktur Yang Terdaftar Di Bursa Efek Indonesia Periode 2007-2009). Sekolah Tinggi Ilmu Ekonomi Widya Manggala. Semarang.

Ross, S.A, 1976. The determination of financial structure: The incentive-signalling approach, Bell Journal of economics, 8, 2340. 